\title{
Alternative Economies as Marketing Systems? The Role of Value Creation and the Criticism of Economic Growth
}

\author{
Michaela Haase, '®i Ingrid Becker, ${ }^{2}$ and Doreén Pick ${ }^{3,4}$
}

\begin{abstract}
Actors engaged in alternative economies organize resource transfers, exchange resources (with and without the use of money), and create value. As value creation is a definitional attribute of marketing systems, we examine whether alternative economies fall under the concept of marketing systems. That is, the conceptual framework of the marketingsystems approach applicable to alternative economies must help answer this question, and the approach's empirical claims must hold true in alternative economies. We refer to the distinction between the conceptual framework of a theory and its empirical claims to substantiate our notion that alternative economies are marketing systems. Informed by the theoretical analysis and insights gleaned from interviews, we suggest modifications of the conceptual framework of the marketing-systems approach to improve or extend its applicability to alternative economies.
\end{abstract}

\section{Keywords}

marketing systems, alternative economies, conceptual framework, flexible inductive research, value creation, value, growth

\section{Introduction}

New forms of economic organization emerged or were "revitalized" under the heading of "alternative economy," and a wide range of phenomena is related to that concept. Contemporary instances of alternative economies arose when people connected with like-minded others in networks supporting or enabling collaborative consumption and resource sharing or founded collectivities such as food-sharing initiatives or give-away shops, that is, free shops or umsonstläden (Bianchi and Birtwistle 2010), time banks (Del Moral 2014; Laamanen, Wahlen, and Campana 2015; Papaoikonomou and Valor 2017; Seyfang 2003, 2004; Seyfang and Longhurst 2016; Valor and Papaoikonomou 2014), urban or community gardening initiatives (Alaimo, Reischl, and Allen 2010; Wakefield et al. 2007), or local currency systems (Chang 2012; Lloveras and Ntounis 2014; Seyfang 2004; Seyfang and Longhurst 2016).

Owing to the sustainability megatrend (Mittelstaedt et al. 2014) and the recent financial and economic crises, alternative economies have attracted the attention of scholars and lifeworld actors. In a recent special issue of the Journal of Macromarketing, scholars deepen the understanding about alternative economies by addressing this fragmented field with a particular focus on social paradigms, institutional logics, and the "implications of alternative economies to individuals, localities, markets, and society" (Campana, Chatzidakis, and Laamanen 2017, p. 127).
Considering the lack of an accepted definition of the concept of alternative economy, we offer a preliminary one. This working definition derives from our qualitative study and a literature review on de-growth and post-growth; sustainability and business ethics; and ethical, solidarity, and alternative economies (e.g., Fournier 2008; Gibson-Graham 2003; Gibson-Graham and Roelvink 2011; Hiwaki 2015; Jackson 2009a, 2009b; Laczniak and Santos 2011; Latouche 2009). We propose that an alternative economy is an economy within which actors (1) strive to avoid the effects of economic value creation that harm society or nature, (2) reject the separation of the social and economic spheres, (3) perceive and accept their responsibility for their social and economic activities and the consequences of these activities in the social and natural realms, and (4) attempt to engage in new or re-vitalized forms of socio-economic practice. In other words, actors in alternative economies pursue value creation in a way that expresses relationships between human beings and between human beings and nature that differ from those characteristic of "regular" or non-alternative

\footnotetext{
'Freie Universität Berlin, Berlin, Germany

${ }^{2}$ Friedrich-Alexander-Universität Erlangen-Nürnberg, Erlangen, Germany

${ }^{3}$ Hochschule Merseburg, Merseburg, Germany

${ }^{4}$ FOM Hochschule Berlin, Berlin, Germany
}

\section{Corresponding Author:}

Michaela Haase, Freie Universität Berlin, Arnimallee II, I4I95 Berlin, Germany. Email: michaela.haase@fu-berlin.de 
economies. Conditions (1) to (3) determine what is important for alternative-economy actors; condition (4) determines that they actually act or try to act in the way they consider being right or indicated. According to condition (4), it is not required that alternative-economy actors invent new forms of socioeconomic practice. Thus, alternative economies are not necessarily a contemporary phenomenon only. For example, William S. Jevons (1866), one of the founders of neoclassical economics (Nutzinger 2012), favored workers' co-operatives.

Alternative economies can be structured and purposeful entities as well (for a similar view with respect to marketing systems, see Layton 2011). Actors engaged in alternative economies organize resource transfers and exchange resources (with and without the use of money). We share the service-dominant (S-D) logic's and consumer culture theory's view that many of the activities performed in economies are devoted not to exchange (Karababa and Kjeldgaard 2014, p. 122) but to value creation. As value creation is a definitional attribute of marketing systems, we examine whether alternative economies fall under the concept of marketing system. The conceptual framework of the marketing-systems approach applicable to alternative economies (see Layton 2007) helps answer this question, and that the approach's empirical claims hold true in alternative economies. According to Layton (2011, p. 259), "[a] marketing system is a network of individuals, groups and/or entities; embedded in a social matrix; linked directly or indirectly through sequential or shared participation in economic exchange; which jointly and/or collectively creates economic value with and for customers, through the offer of; assortments of products, services, experiences and ideas; and that emerge in response to or anticipation of consumer demand."

The marketing-systems approach and other strands in marketing studies recognize alternative economies as research objects. Layton (2015, p. 305) notes that different types of marketing systems "often co-exist in differing layers or levels of economic activity," and he named the entities or phenomena studied within the field of alternative economies, encompassing re-use, recycling, and disposal systems, as "post-consumption marketing systems." Varey (2010) uses the expression "sustainable marketing system" to capture the increasing relevance of sustainability in market relationships and the evolution of social structures toward a "post-consumption era." For Varey (2010, p. 120) the concept of sustainable marketing system "is intertwined with the notion of marketing that is socially responsible (Lazer 1969), nondestructive (Hart and Milstein 2003), value driven and relational (Varey 2002a, 2002b), and cocreative (Prahalad and Ramaswamy 2004)."

Using the working definition of "alternative economy" (a conceptual matter), we can identify the entities that fall under the definition (an empirical matter), though this does not imply that the respective entities are marketing systems as well. What might appear at first glance as alternative economies as marketing systems is not so obvious when assessing extant literature or considering the information gained from the people engaged in them. Therefore, whether alternative economies fall under the concept of marketing system is an open question. In addition, what constitutes an argument suitable to substantiate the claim that alternative economies are marketing systems? Our proposal refers to the distinction between the conceptual framework of a theory and its empirical claims; as such, we argue that the conceptual framework of the marketing-systems approach is in need of adaptation to improve or extend its applicability to alternative economies.

As exemplified by our approach, conceptual problems relate to empirical problems in two respects: first, empirical insights can change concepts (or conceptual frameworks) or theories, and second, concepts are part of the language used to address empirical phenomena. Because human beings cannot deal with phenomena themselves, but only with phenomena couched in language, phenomena and language are not independent of each other. The relevant languages for our research are the language of the people engaged in alternative economies (everyday language) and the language of scholars studying alternative economies (which differs from the language of economics or marketing studies in most cases).

Three related perspectives arose with regard to understanding the expression "alternative economy." First, the very meaning of the word "alternative" indicates that alternative economies do not belong to the class of economic phenomena. While the word "economy" signals conformity of the alternative-economy phenomena with economic phenomena, the word "alternative" means rejecting any association of these phenomena with the economy. Second, alternative economies differ from non-alternative economies. Thus, the word "alternative" indicates that though alternative economies are economic phenomena in some respects, they are not in other respects - for example, the valuation of resources integrated in value creation processes. The critical stance on capitalism and growth prevailing in alternative-economy scholarship and practice (Gibson-Graham 2006; Lloveras and Quinn 2017) is in accord with this observation as well. Third, economics is rejected as the language used for the representation of alternative economies. With respect to the de-growth movement, Fournier (2008, p. 529) suggests that "we need to escape from the economy as a system of representation." That is, the de-growth movements need to escape from economics as a system of representation. If alternative economies are conceptualized in terms of economics, it would be difficult to consider them something alternative to "regular" economies.

A conceptualization of alternative economies in terms of the marketing-systems approach avoids the contradictions included in the first and third perspectives. We hold the view that, though different, alternative economies are economies. Value creation is not only an important characteristic of both alternative economies and marketing systems but also the key to understanding alternative economies, in terms of both their economic characteristics and these characteristics' stance on "established economic wisdom."

Theoretically, we draw on Layton's (2011) exposition of the marketing-systems approach and Mittelstaedt, Kilbourne, and Mittelstaedt's (2006, p. 135) fundamental statement of macromarketing theory that paves the way for studying various types 


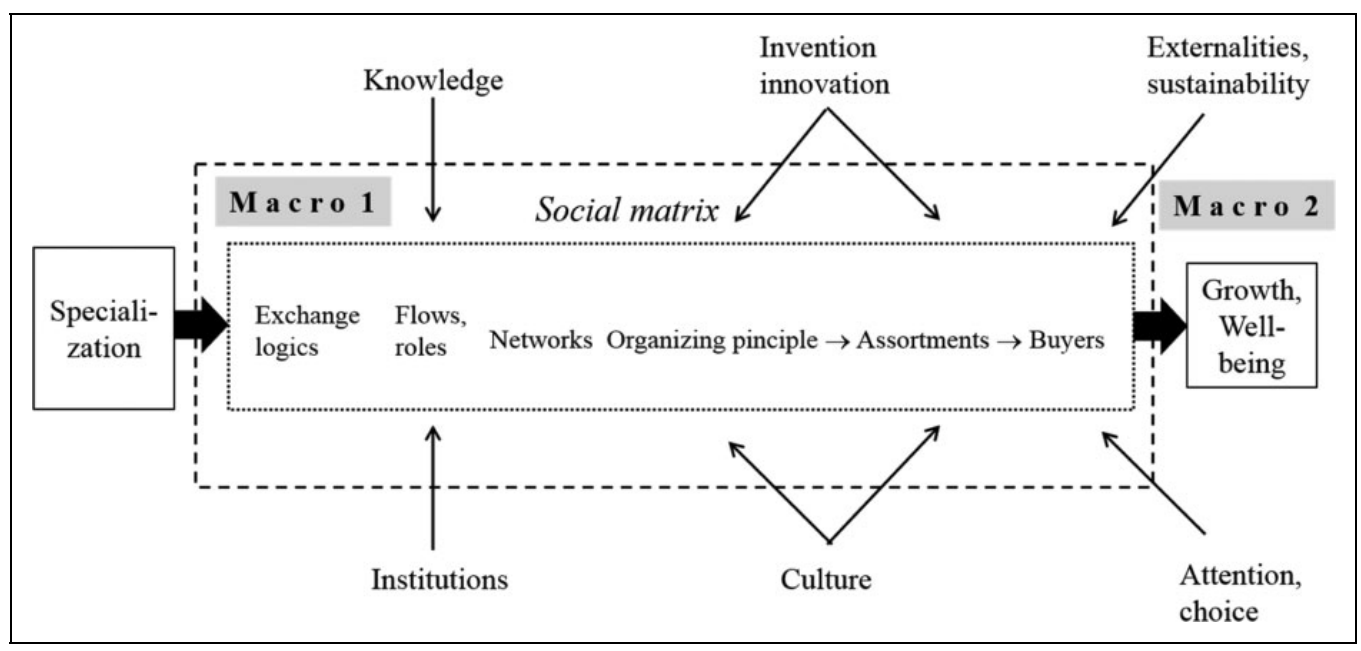

Figure I. Marketing system and social environment (adapted from Layton 2009, p. 359, Figure 4).

of marketing systems: "macromarketing is focused on questions of what constitutes heterogeneity and on 'why' and 'how' heterogeneity exists." The alternative-economy literature also emphasizes the heterogeneity of alternative economies, linking it to an attempt to create differences in how things are done in regular economies (Gibson-Graham 2006).

This paper contributes to macromarketing research in three ways. First, it provides a working definition of "alternative economy" that bridges the concept of alternative economy in extant literature and the marketing-systems approach. Second, we suggest a change in the conceptual framework's list of essential components. In particular, we propose putting more emphasis on value creation than is currently expressed in the marketing-systems approach and extending the conceptual framework by including social and ecological value. Third, we suggest addressing two macro levels of analysis (macro 1 and macro 2) and, consequently, argue that two types of social mechanisms (micro-macro 1 and micro-macro 2) are relevant for the understanding of marketing systems.

In the next section, we address value creation in marketing systems and wealth/growth as outcomes of marketing systems, with reference to the established conceptual framework of the marketing-systems approach. After that, we carry out a smallscale empirical study (qualitative interviews) to improve the understanding of alternative economies. Next, we present the research design and findings. Informed by the theoretical analysis and insights gleaned from our interviews, we then suggest modifications of the conceptual framework of the marketingsystems approach. In the final section, we re-address our research question, discuss potential consequences resulting from our study for both macromarketing scholars and alternative economies, and present a brief outlook for future research.

\section{Value Creation in and Outcomes of Marketing Systems}

We argue that actors participating in alternative economies are engaged in value creation. That is, they create what we call "economic value," or value for themselves, their relatives, or stakeholders. In addition, some actors in alternative economies are highly concerned about the consequences of their actions on society/nature and critically reflect on the influence of consumerism and growth ideologies on their "way of life" (Lloveras and Quinn 2017). In this context, Fournier (2008, p. 533) argues that alternative economies comprise the de-growth movement and its political ends, though she delimits this to entities that "start with value and politics [and] oppose economic determinism or 'economism' by going back to the terrain of the political." For this reason, extending Haase's (2015) value creation framework to the study of marketing systems, we distinguish three types of value (economic, social, and ecological), describe for whom the value is created (the individual actor, the organization and its stakeholders, the community, society, or nature), and delineate the intended outcome of the marketing system at the macro-2 level (growth or wealth). Next, we briefly introduce the standard representation of the marketing system (see Figure 1), slightly modified by our distinction between the two macro levels of analysis.

\section{Social Matrix, Macro I, and Macro 2}

The marketing system is the basic unit of analysis in macromarketing theory (Layton 2007, 2009, 2011; Layton and Grossbart 2006; Mittelstaedt, Duke, and Mittelstaedt 2009; Mittelstaedt, Kilbourne, and Mittelstaedt 2006). Layton (2011) defines the concept of the marketing system and explains the meaning of the concepts included in the definition's definiens. He also provides lists of concepts outlining the field of current and future research.

The performance of marketing systems depends on human action, not on chance (Layton 2015). Erected against the backdrop of a certain level of specialization (division of labor) and designed to achieve micro- and macro-level objectives, the marketing system contains what Layton (2011, p. 267) calls "essential components": exchange logics, flows and roles, networks, governance, assortments, and buyers (see dotted lines in 
Figure 1). A key element of marketing systems is the social matrix, or the characteristics of the marketing system's environment relevant to its study (see expressions above the dashed line in Figure 1). Thus, the term "social matrix" symbolizes the embeddedness of the marketing system within the environment. It expresses both the effects of the environment (characterized by myriad variables) on the marketing system and the influence of the marketing system on the environment (externalities, sustainability). The social matrix mirrors the three basic classes of determinants of heterogeneity, as identified by Mittelstaedt, Kilbourne, and Mittelstaedt (2006): formal, informal, and philosophical antecedents. The study of formal antecedents includes law and regulatory structures; informal antecedents include cultural, ethnic, and religious aspects; and philosophical antecedents "are those factors that shape perceptions of the role of markets and marketing systems in people's lives" (Mittelstaedt, Kilbourne, and Mittelstaedt 2006, p. 135).

Figure 1 represents the conceptual framework of the marketing-systems approach and identifies two macro levels: macro 1 , which is the marketing system embedded in the social matrix, and macro 2 , which is the environment and outcome of the marketing system at a higher level of analysis or abstraction.

\section{Value and Value Creation in Marketing Systems}

According to the definition of the concept of marketing system (Layton 2011), all actors pursue the creation of economic value. Value creation is a means to achieve individual or organizational ends (Edvardsson et al. 2014) — that is, value. As Karababa and Kjeldgaard (2014, p. 120) remark, the "notion of economic value is founded in classical and political economy." In this regard, we refer to subjective value theory (Haase and Pick 2015; for a systematic account of the history of economics, see Stavenhagen 1969, p. 227 ff.).

We mainly refer to the distinction between values (in the axiological sense ${ }^{2}$ ) and value in the economic sense. Drawing on Kluckhohn's (1951, p. 395) view that value is a kind of "conception of the desirable," we regard value, values, and valuations as essentially related. Value in the linguistic sense (Graeber 2001) is not the focus of our analysis. However, the meaning of words (or "value"), the languages using these words, and value creation practices are essential for understanding the three types of value we distinguish. As Edvardsson, Bard, and Gruber $(2011$, p. 334) argue, "the value of products (as well as of any other resource or outcome, authors) depends on the social consensus about such value." A social movement, such as the de-growth movement, can be characterized by a change in such a consensus and the achievement of a new consensus.

The economic value-creating activities include exchange, resource transfers, resource integration, and use processes. The resources integrated in value creation processes are available to their users; they are accessed via exchange or are a result of preceding value creation processes conducted by users themselves. Through value creation processes, resources are transformed into other resources (Kleinaltenkamp et al. 2012); for this reason, Karababa and Kjeldgaard (2014, p. 121) characterize economic value as "the function of a product." Thus, resource transformations are not the actors' final ends but a means for achieving what is of value to them and, with it, what contributes to the achievement of higher-level ends, such as benefits, utilities, profits, quality of life, or well-being. While economic value creation is a definitional attribute of the marketing system, its definition does not determine what the actors want to achieve through their respective activities. We subsume all valued consequences of use processes of resources, intended to serve the actors' interests, under "economic value." For economic value creation, the main beneficiary is the actor him- or herself. However, the benefit of the actor's relatives, cooperation partners, or stakeholders can be included in the range of his or her self-interest.

The monetary or non-monetary resources that are inputs and outcomes of transformation processes are not value. Value is an expression of subjective assessment (Haase and Pick 2015). Despite the intended achievement of value as a consequence of valuations of (or within) value creation processes and the expected positive results of these processes, the valuations of these results are not necessarily positive (see Echeverri and Skålén 2011); valuations can also be negative.

In the creation of economic value, the beneficiary is the actor or his or her stakeholders. However, actors can also be concerned about the social and ecological consequences of their activities. We hypothesize that actors engaged in alternative economies are more concerned about such consequences than actors in "regular" economies. In our conceptualizations of "social value" and "ecological value," we introduce beneficiaries who have largely been neglected in the discussion of economic value creation. From our perspective, the actors engaged in alternative economies intend to create value also for entities included in the social sphere (e.g., groups, communities), the natural sphere (e.g., animals, community parks, rivers, valleys), or, generally speaking, society or nature. Our approach to the creation of social value connects with the idea that some social value was not created, but could have been: "Proponents of degrowth question the social utility ${ }^{3}$ of creating or protecting meaningless or even harmful jobs, for example, they ask: What kind of jobs? To produce what? For whom? Leading to which consequences? For what social utility?" (Fournier 2008, p. 535). To define "ecological value," we draw on what Mang and Reed (2015) call a biocentric perspective. They define value "in terms of benefits to the systemic capability to generate, sustain and evolve life of a particular place" (p. 7) or, more briefly, "in terms of benefits to life" (p. 8).

When considering value for communities, society, or nature, researchers face the problem that not all "recipients" of this value can make the required valuations themselves, at least not in a direct manner. This is especially true for natural entities, ecological systems, networks, or society. Actors assess the value of their actions for these entities in accordance with various sources (e.g., experience, beliefs, ideology, knowledge). To create value for another entity, actors can rely on their own assessment. However, the subjective foundation of 
assessments can and should be complemented by an objective one (Burger et al. 2011; Cole 2015; Mang and Reed 2015; Ordóñez and Duinker 2014). The latter alternative requires developing knowledge about the effects of social mechanisms (Layton 2016) and of "new metrics and methods to evaluate success" (Cole 2015, p. 5). Measurement (or other forms of data generation) may be desired, but an adequate procedure is often not available at a given point in time. This is especially true in the case of social and ecological value. As Mang and Reed (2015, p. 8) stress with respect to ecological value, human beings are at the beginning of thinking about such a "value-adding role in the ecological systems where they are constituents," and this also holds true for the definition of value concepts and the measurement of value.

Although we extend the actors' intended results of their value creation processes to social and ecological value, we do not make this extension a definitional characteristic of the concept of marketing system. That actors intend to create social or ecological value is an empirical, hypothetical statement-a potential candidate for a "law-like" generalization within the marketing-systems approach. In the next subsection, we compare the creation of social or ecological value as intended action consequences with negative externalities deemed unintended action consequences. In this regard, our approach goes a step beyond the avoidance of negatively assessed action consequences (Lautermann 2013).

\section{Value, Social Consequences, and Externalities}

In our framework of analysis, ${ }^{4}$ value is an intended action consequence. However, value creation processes can also have unintended consequences, some of which have been addressed in terms of externalities (Fry and Polonsky 2004; Layton and Grossbart 2006; Mittelstaedt, Kilbourne, and Mittelstaedt 2006; Mundt 1993; Shultz 2007; Shultz and Holbrook 1999).

We refer to Nason's (1989, p. 242) characterization of social consequences and their distinction from externalities to compare value in this regard with other forms of action consequences: "A social consequence of a market transaction, as used here, is any unforeseen effect, positive or negative, experienced by the parties to the transaction or any effect, foreseen or not, experienced by others not party to the transaction." Because any social consequence comes as a surprise to a given actor, the effect is incalculable. In contrast, most of the externalities debated today are negative and do not come as a surprise to actors. As such, they are usually anticipated but not calculated. Mittelstaedt, Kilbourne, and Mittelstaedt (2006) discuss an imaginary two-by-two table that connects positive and negative action consequences with intended and unintended action consequences, and they relate social consequences of marketing and externalities to this table. With this imaginary table, externalities can be anticipated but not intended (see Table 1). According to our approach, economic, social, and ecological value are each anticipated (because each is an explicit end of value creation processes) and (with respect to the resources or costs required to achieve these ends) calculated.
Table I. Comparison of Social Consequences, Externalities, and Value.

\begin{tabular}{llll}
\hline & $\begin{array}{l}\text { Social } \\
\text { consequences }\end{array}$ & Externalities & Value \\
\hline Anticipated & No & Yes, "might be foreseen" & Yes \\
Calculated & No & No & Yes \\
\hline
\end{tabular}

\section{Marketing Systems as Purposeful Entities}

Vargo (2011, p. 221) emphasizes that "fully understanding [marketing] systems requires micro, meso, and macro perspectives." In this subsection, we address the relevance of the distinction between macro 1 and macro 2 in the assessment of outcomes of value creation processes from the perspective of the actor. Depending on the level of analysis and the type of knowledge involved (everyday or scientific), the assessment of the intended and unintended consequences of value creation processes and the assessment of the purpose of the marketing system can differ. The idea that value can be "created" for beneficiaries as different as individuals, organizations, communities, animals, societies, or nature gives reason to study phenomena but necessitates considering different levels of analysis and their interaction: micro-level phenomena (value for the individual), macro-1-level phenomena (e.g., social value for communalities, networks, and particular groups; ecological value for non-human beings, such as rivers), and macro-2level phenomena (value for abstract entities such as society or nature). Macro-1-level phenomena involve the concrete marketing systems within which the actors act; thus, they are "closer" to the experiences of these actors than macro-2-level phenomena (for a similar view, see Graeber 2001, p. 78). In this regard, the "environments" of the social matrices are often beyond individual experience. Actors can assess a concrete marketing system with regard to macro-1-level consequences of micro-level action; however, it is difficult to evaluate a marketing system's contribution to, for example, the quality of life in all societies. Thus, "the efficiency and effectiveness with which each individual marketing system does what it does, is a critical determinant of the quality of life in all societies" (Layton 2011, p. 260; see also Laczniak and Santos 2011; Vann and Kumcu 1995).

Shultz and Holbrook (1999, p. 218; italics in the original) raise the question whether "business activities, marketing plans, and consumer products are commons-friendly, that is, the extent to which they work toward sustaining commonly shared natural resources." In line with our distinction between macro 1 and macro 2, the question arises whether commonsfriendly products actually lead to commons-friendly marketing systems (social or ecological value at the macro-1 level) and whether these systems actually contribute to the creation of social and ecological value at the macro-2 level. "Even when well-intentioned,... ecologically oriented green efforts and activities may be misguided" (Shultz and Holbrook 1999, p. 218), and actors can fail at both the macro-1 and macro-2 
Table 2. Intended and Unintended Action Consequences at Two Macro Levels.

\begin{tabular}{|c|c|c|c|}
\hline Consequences & Micro level & Macro-I level & Macro-2 level \\
\hline Intended & $\begin{array}{l}\text { Economic value } \\
\text { Beneficiaries: } \\
\text { Actors, cooperation } \\
\text { partners, } \\
\text { stakeholders }\end{array}$ & $\begin{array}{l}\text { Social value } \\
\text { Beneficiaries: groups, communities, networks } \\
\text { Ecological value } \\
\text { Beneficiaries: } \\
\text { Animals and non-human entities within the marketing system }\end{array}$ & $\begin{array}{l}\text { Social value } \\
\text { Beneficiary: society } \\
\text { Ecological value } \\
\text { Beneficiaries: the entities in the } \\
\text { environment of the marketing system; } \\
\text { the ecological system }\end{array}$ \\
\hline
\end{tabular}

level. That is, the desired, positively assessed consequences of value creation processes at the macro-1 level may not occur or may be positive at the macro- 1 level (the marketing system) but negative at the macro-2 level (the system's environment). This broader perspective sheds light on the purposiveness of a single marketing system to cope with issues of broader interest described in terms of "the commonly shared environment" by Shultz and Holbrook (1999) or as "megatrends" by Mittelstaedt et al. (2014). In Table 2, we tie intended and unintended action consequences to the macro-1 and macro-2 levels of analysis, respectively.

We do not address wealth in Table 2 because we presume that the relationship between wealth and value needs further investigation. As micro dimensions, we exclude subjective well-being and related concepts, such as happiness (White 2013), from Table 2 as well.

\section{Wealth and Growth as Outcomes of Marketing Systems}

Wealth and growth are outcomes of the marketing system (Figure 1). According to Beinhocker (2006), answers to questions such as what is wealth, how is it created, and how can it be increased can be found in various theories, not just economics. Regardless, there is a long history of theories of wealth in economics, ${ }^{5}$ which is helpful to understand why growth is considered relevant at all. "Growth" means a positive change of a measure related to wealth; thus, growth is not an end in itself. Most theories of wealth assume that the limits to growth are tantamount to a danger to social wealth (Nutzinger 2012). Note that the concept of wealth has no unique meaning. Natural resources (soil or land use), capital goods, labor, and knowledge are all origins of wealth. Wealth is coupled with diverse sources of material richness but also with richness in terms of non-material entities.

More recently, Layton (2009, p. 352), discussing the ideas of new classical economics on wealth creation, addressed "the processes that lead to wealth creation." While "value" can denote "value for an individual," wealth is an important macro concept (Mittelstaedt, Kilbourne, and Mittelstaedt 2006; Varey 2012) related to princely families, kingdoms, or nations.

So far, we have discussed concepts and distinctions originating from theory: the marketing system as determined by the social matrix, the essential components and further lists of concepts, and the distinction between two macro levels of analysis. In the next section, we briefly introduce the research design underlying the empirical part of our analysis.

\section{Qualitative Interviews: Sampling, Design, and Analysis}

The perspectives of actors engaged in alternative economies are an important source of information for our discussion on the conceptual framework of the marketing-systems approach. In summer 2015, we conducted eight in-depth qualitative interviews varying in length between 1 and 2.5 hours. We collected data from participants whose activities or projects we deemed as conforming with those conducted in alternative economies (according to our working definition) or who identified themselves with post- and de-growth aims. The sampling strategy was primarily purposive, which means we selected participants according to their suitability to represent rich and informative cases (Christensen, Johnson, and Turner 2015). As founders of their organizations or as key decision makers, all participants are suitable to comment on our questions (Wilson 2014). We established initial contact with respondents by e-mail, explaining the research purpose. Personal telephone calls followed the e-mail contacts. By adopting an empathetically neutral and mindful position (Christensen, Johnson, and Turner 2015), we conducted interviews personally, and each interview was recorded. No incentives were given for interview participation. Table 3 provides a description of the sample.

Christensen, Johnson, and Turner (2015) regard the engagement of multiple researchers ("investigator triangulation") as a useful strategy for obtaining descriptive validity. Therefore, all authors were involved in conducting and analyzing the interviews. In line with Sridharan et al. (2014), each interview was analyzed independently by each author and then mutually discussed. All authors also independently back-translated the verbatim quotes cited subsequently to ensure intercoder reliability.

We chose a semi-structured interview approach to ensure that all aspects of relevance were covered on the one hand and provided the flexibility to probe for further details on the other hand. The interview questions addressed the following aspects: 
Table 3. Organization / Informant Profiles.

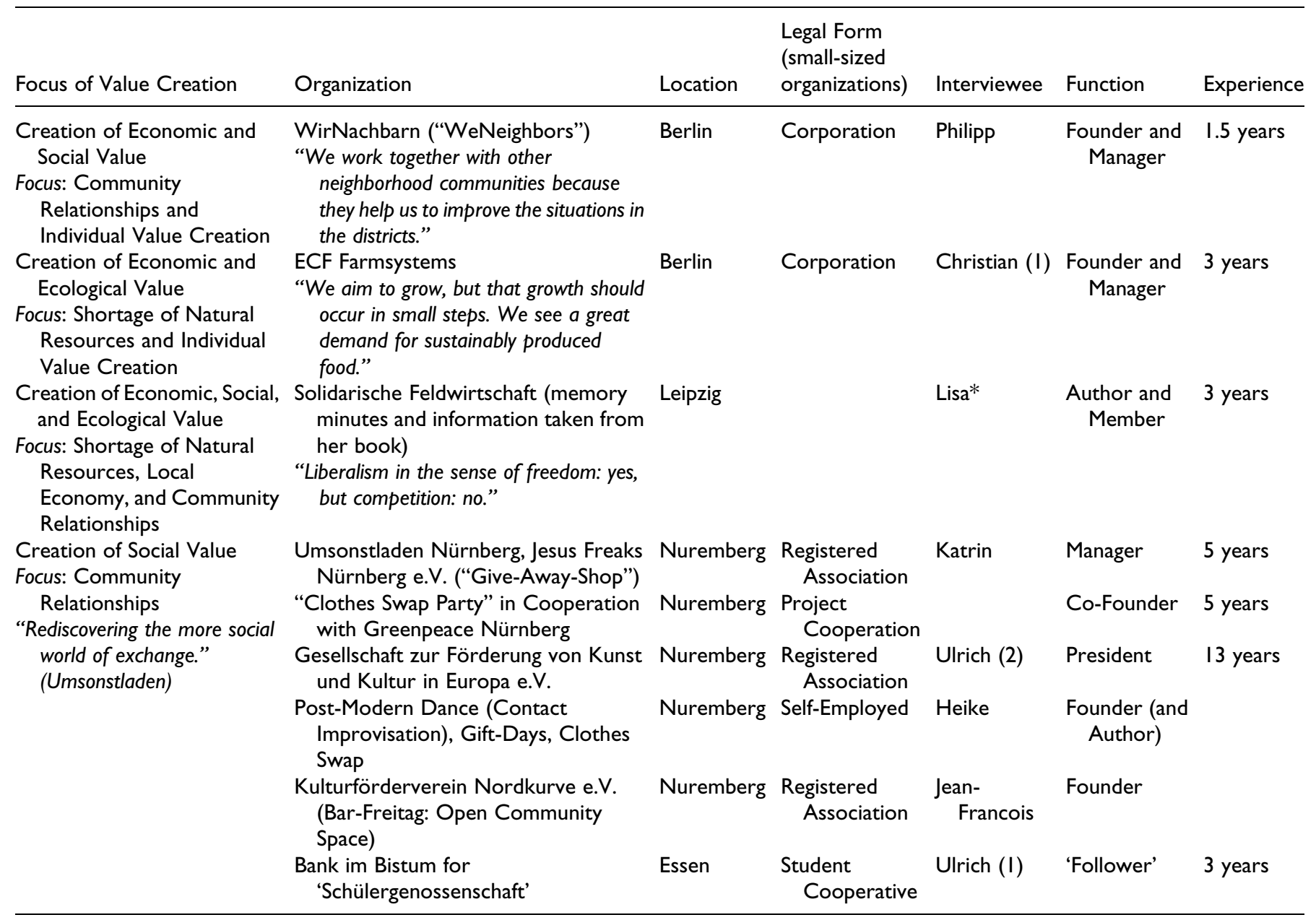

1. How do participants in alternative economies understand and describe the social phenomena whose realization they are involved in?

2. What are the outcomes participants aim to achieve for themselves and the resources required to do so?

3. How do participants make sense of their impact on collective action units, communities, and relationships within concrete marketing systems (i.e., macro-1 level)? What do they think about the impact of alternative economies on the marketing system's social and ecological environment (i.e., macro-2 level)?

Respondents were encouraged to talk in depth (Wilson 2014). Furthermore, open questions allowed us to identify the different ways of understanding and to follow topical trajectories that emerged during the conversations. Hodkinson's (2016, p. 112) flexible inductive research approach, in which themes emerge "as a result of an ongoing and flexible synthesis of research data with concepts and priorities from existing literature," guided our data analysis. The results of the analysis guided the modification of the conceptual framework outlined in the next section. Accordingly, we underpin our suggestions with quotes from our interviews.

\section{Modification of the Conceptual Framework}

In thriving theories, conceptual frameworks are not static and complete entities. In case of social-scientific theories, a conceptual framework can change for several reasons, such as the framework's connection with other theories and the empirical evidence gained from observation and other forms of empirical research. As Alvesson and Kärreman (2007, p. 1270) state, "the empirical material has a very important and critical role as dialogue partner." In our case, "modification of the conceptual framework" means a change in the hierarchy of concepts in the conceptual framework and the inclusion of additional concepts. Concretely, we upgrade the concept of value creation; that is, we add "value creation" to the list of essential components and remove "growth" from the list of outcomes of marketing systems.

\section{The Essential Components and the Hierarchy of Concepts}

In this subsection, we discuss the essential components of the conceptual framework of the marketing-systems approach. On a case-by-case basis, we integrate verbatim quotes from the interviewees to enrich our argumentation. 
Exchange logics. According to Layton (2011, p. 268), the "exchange logics and contexts associated with a transaction set at the core of a marketing system" can be diverse. That something is "at the core" of something else is an expression of relevance. It is a matter of empirical investigation to determine the role of market exchange in alternative economies or what other systems of exchange exist (for a discussion, see Graeber 2001). It is beyond a doubt, however, that market exchange plays a role (Gibson-Graham and Roelvink 2011). Alternative economies are in need of resource transfers and conduct exchange for the sake of value creation:

I further believe that there are various benefits to the users. Some activities focus on product exchange, with users thinking "I need something or aim to give something for the use of others." (Philipp)

Yet market transactions are not "at the core" of alternative economies. Therefore, in alternative economies "logics" other than just exchange logics might be at work. We presume that the study of exchange logics can be embedded within interdisciplinary research devoted to "institutional logics." Institutional logics are "a set of material practices and symbolic constructions ... which [are] available to organizations and individuals to elaborate" (Friedland and Alford 1991, p. 248). "Institutional logic" is a construct that adds a social dimension to the study of actors' ends, addresses the role of institutions and values in this regard, and highlights the relevance of ideas and beliefs to the study of marketing systems (see Edvardsson et al. 2014; Thornton and Ocasio 1999). Actors make use of logics (Gawer and Phillips 2013; McPherson and Sauder 2013) or put them into action (Lounsbury and Boxenbaum 2013). "Institutional logics" is a "cluster concept" that inextricably relates the three antecedents to the heterogeneity of marketing systems to one another.

Assortments. "For most buyers/customers within a marketing system, it is the ability to provide assortments that enable them to fulfill their needs and wants that will determine the perceived success or failure of the marketing system" (Layton 2011, p. 272). Here, Layton refers to the interaction between micro- and macro-level characteristics. The aforementioned ability of marketing systems is related to the creation of economic value as an intended result of value creation processes. Layton addresses goods, services, experiences, and ideas under the heading "assortments." From the S-D perspective that underlies our discussion of value creation, assortments are resources for the actors' value creation processes. To fulfill their needs and wants, actors must integrate resources such as physical objects, skills, information, space, and time - as a consequence of our discussion, we substitute the broader term "resource" for "assortment." Use processes give rise to interactions and the development of networks that appear in the form of sharing, collaborative consumption, volunteering, or collective space. For example, with giveaway shops, people are offered resources for their value creation activities and, at the same time, experience what it means to support others in a local environment (see Chatzidakis, Maclaran, and Bradshaw 2012):

You need an element [or resources] - such as tangible goods - to establish connections between people. When you approach people on the street, they might suspect an agenda. In contrast, our "shop" provides a platform for people to get to know each other, without feeling uncomfortable. (Katrin)

Flows. A basic reason for the exchange of resources and rights and, with it, flows in the marketing systems is the actors' interest in resources they plan to integrate with the resources of others. Layton (2011, p. 272) argues that the "heterogeneity of resource endowments or capabilities of purchasers, including capacity to pay, will be an important determinant of system functions and structure." Indicative of the heterogeneity of alternative economies are the diverse reasons and mechanisms for flows of resources (Gibson-Graham and Roelvink 2011). Markets, however, are not involved in every instance of resource flows. Research has addressed other determinants of resource flows, such as social sharing (Benkler 2004). If resources are transferred within neighborhood circles whose members promise one another access to resources that are their personal property, markets are not immediately involved in these processes either.

Actors cannot unfold their competences if they are not allowed to make use of resources; that is, if the respective property rights are not granted to them. Actors use their competences or mega-competences (Lusch, Vargo, and Malter 2006) based on the flow of resources and rights. Frow and Payne (2011, p. 234) refer to mega-competences as well, stating that they are "important in facilitating knowledge sharing: collaborative capability - the ability to work with other parties in an open, honest, and symmetric manner; and absorptive capability which involves being able to absorb new information from stakeholders and the environment."

The development of people's capabilities or competences (reskilling) through participation in the initiative is in the foreground, not the production of a marketable outcome. (Lisa)

Roles. According to Layton (2011, p. 270), "each participant fills one or more roles in the operation of a marketing system." The social interaction of role bearers whose behavior reflect social norms is a main element in social theory and constitutive of the understanding of social systems (Miebach 1991). In their notion of non-human role players, Mang and Reed $(2015$, p. 9$)$ assume that species fulfill roles in ecological systems and that the value of a role derives "from the pattern of relationships that enable particular exchanges of value." Prior research in business-to-business and businessto-consumer marketing has addressed the interactions between role bearers (e.g., providers and customers). However, the S-D logic overthrows such division of roles: "It's all actor-to-actor" (Lusch and Vargo 2014, p. 101). 
Actor-to-actor interaction is a fundamental category that transcends classic role ascriptions, such as customer-provider or buyer-seller. These role ascriptions might still be useful in the analysis of relationships. Yet, in alternative economies, key role ascriptions, such as "buyer" and "seller," have lost importance. Actors indicated that they would never take roles they perceive as "market-determined" (see, e.g. Schor and Fitzmaurice 2015); instead, they take other and multiple roles. Some actors view themselves as initiators (Philipp) or "institutional entrepreneurs" (Jean-Francois) who can foster the change of cognitive institutions (DiMaggio 1988; Scott 1995):

Obviously and in general, I have the role of the initiator. Sometimes, I feel also having different roles, such as a booster, for example. In sum, I would say my role is to cover $60 \%$ of all tasks. (Philipp)

People are not used to entering public space where no commercial activities are taking place. (Jean-Francois)

Other actors perceive themselves as multipliers for developing (external) relationships:

I regard myself as a multiplier, communicating our idea to others, including those who wouldn't normally participate. (Katrin)

Furthermore, we observed that roles can change within alternative-economy initiatives (dynamics of roles). For example, a formerly very active founder can adopt a more passive role over time (Jean-Francois).

Networks. According to Layton (2011, p. 271), actors "are linked directly or indirectly through sequential or shared participation in exchange transactions, jointly creating economic value through the offer of assortments." By definition of the concept of marketing system, networks "lie at the core of any marketing system" (Layton 2011, p. 271) and "develop based on shared or common interests" (Layton 2009, p. 356). Layton (2011) describes the relationships of network actors in terms of power, influence, trust, expertise, and knowledge.

It's exciting to exchange experiences and share information or to become able to solve problems such as getting access to funding within networks. (Katrin)

Mutual understanding and obligation can characterize the relationships of network members (Layton 2011). An important resource for value creation processes is the social capital generated and maintained in social networks (Mincyte 2008). Compared with corporations, workers' associations, and political parties, a network is not a collective action unit (Coleman 1986) and, therefore, not an actor itself.

Organizing principle/governance. The "overall governance of the system" is devoted to the solution of the "social problem of providing people with desired assortments" (Layton 2011, p.
271). To a large degree, assortments are what buyers want to acquire. Participants in alternative economies aim to solve different types of social problems. Nevertheless, the fact that the marketing system's purpose is the solution of social problems is the common denominator coupling marketing systems and alternative economies in this regard. Actors in alternative economies perform group activities based on various forms of coordination, ranging from less to more institutionalized structures and regulations, that is, the formal and informal antecedents of marketing systems (Mittelstaedt, Kilbourne, and Mittelstaedt 2006). Regarding the student association (see Table 3), we found activities to be formally regulated to coordinate the behavior of actors and to shape mutual expectations within own and corresponding parties' activities. In a staggered process, the board members of the student association take on periods of office that vary in length to pass on internal knowledge and maintain existing structures.

It's a staggered system. Every year, one-half of the board members are replaced. The other half shares their experiences with new members. (Ulrich 1)

Less institutionalized processes characterize other initiatives. Instead of complying with formal rules, participants practice collaborative decision making. Mutual expectations (e.g., of who is responsible for performing which task) result from joint communication. Because of collaborative decision making, internal governance is in a state of flux in some initiatives:

We have conflicts of interest regarding our individual aims or our subjective understanding of what "being active" means. Conflicts of interest begin with how to decorate the "store," but then again, this results in finding a solution together. Everything is amorphous and in constant change. (Katrin)

In the next subsection, we conceptualize marketing systems in terms of actors; value creation and values; expectations and value propositions; and social action in markets, groups, organizations, and networks. Figure 2 contains the three essential components we discuss: actors, value creation, and social action. We add a list of concepts that delineate the respective field of study (see Layton 2007, p. 238) for each concept. From our perspective, these proposals are a starting point for a discussion of possible changes in the list of essential concepts of the marketing-systems approach. In turn, these changes should pave the way for the study of alternative economies within the marketing-systems approach.

\section{Changes in the List of Essential Components}

Layton (2009, p. 355) provides a list of essential components and a detailed list of concepts related to each essential component (see also Layton 2007, p. 238). These lists delineate the field of study and express an order (hierarchy) of concepts in the conceptual framework. We conclude from our preceding discussion that "value creation" should have a higher position 


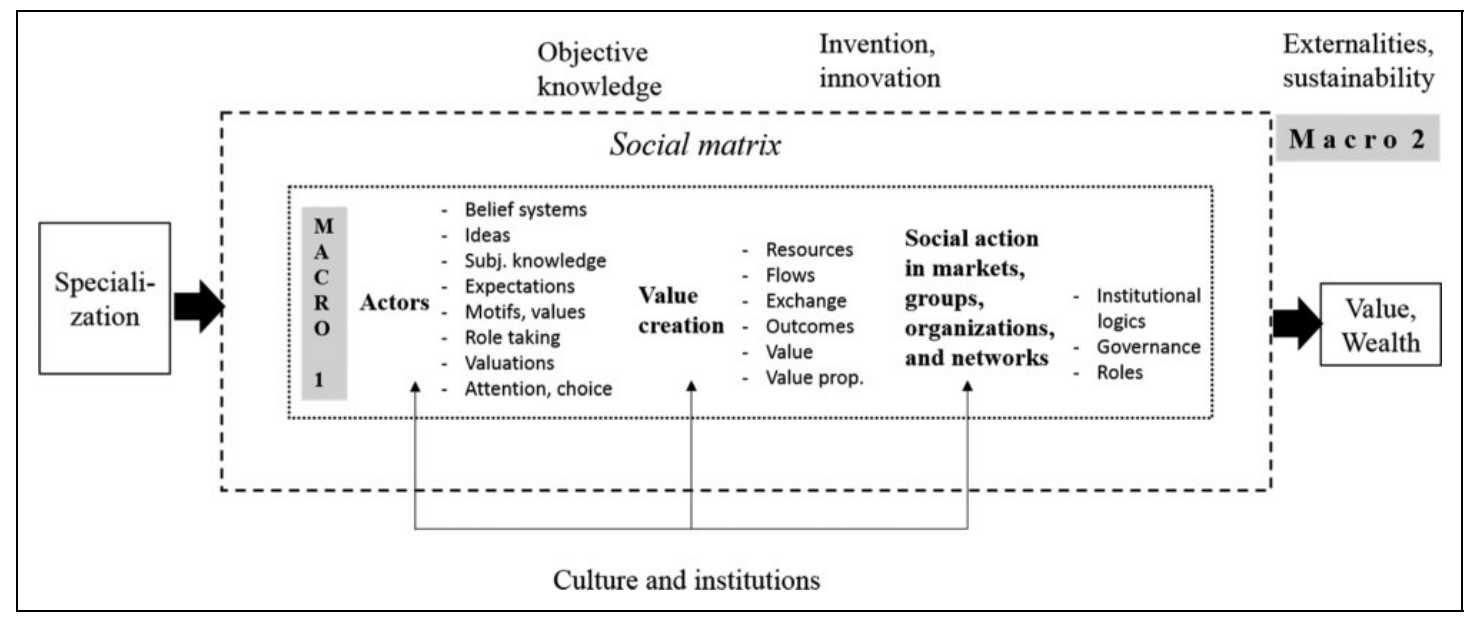

Figure 2. Modified representation of the marketing system.

and "assortments" and "buyers" should have lower positions in the hierarchy of concepts. Because of the close relationship between value creation and exchange, we collocate these concepts in the modified list of essential concepts in Figure 2. The other two concepts added to our list of essential concepts are "actors" and "social action."

Actors. We suggest including "actors" in the list of essential components because we reason that actors are an essential point of reference for the ideas, belief systems, or experiences addressed by the marketing-systems approach. In addition, in the social sciences, many other concepts refer to the concept of actor used to describe marketing systems in terms of activities or processes, intentions and action consequences, purpose, and success. Both individuals and organizations are actors who integrate resources (Kleinaltenkamp et al. 2012), engage in networks (Coleman 1986; Cunningham 2008; Layton 2015; Löbler 2013), and perform institutional work (Lawrence and Suddaby 2006).

Value creation. Resources are not integrated for the sake of creating only individual economic value. According to Layton (2011, p. 269), "The values sought by the participants in exchange may be economic and/or non-economic in nature."

Some people need to work on practical solutions in terms of how to produce less, consume less and destroy less, like the initiatives you are looking at. Others should think about the concepts and ideas that explain, justify, and support these practices. (Heike)

The idea that the "co-creation of value outcomes" (Layton 2011 , p. 269) can lead to value for beneficiaries other than oneself or another individual or organizational co-creator of value is important for actors engaged in alternative economies.

Participation in the initiative is the individual way to live enkelfähig [in a way that saves the earth for next generations] or to live a good life. The achievement of resilience is in the foreground, related to the insight that change cannot be realized by acting in singularity. (Lisa)

Other activities are more emotional. Here, people help each other with the relocation or organization of a block party. These are experiences of community. (Philipp)

From our perspective, the values (neighborhood, community, sustainability, or responsibility) that initiate and guide value creation processes influence the economic, social, or ecological value that actors aim to create. Thus, values are constitutive of the initiation, procedure, and assessment of value creation processes and increase the heterogeneity of marketing systems. Regarding the awareness of social or ecological problems, the actors engaged in alternative economies comprehend that their range of action is limited and that the achievement of their ends requires cooperation:

If it comes to [understanding what] participation in the initiative [means], to save the world is not the main reason, nor relinquishment. It is the achievement of individual value related to the insight that change can be achieved only by cooperation. (Lisa)

Some actors consider the initiative in which they participate a kind of social experiment:

I don't want to consider our project as compensation for the disadvantages resulting from capitalism. It's not our task to question the system. It's the task of researchers to have these discussions, people who are looking at this from outside. Nonetheless, our initiative can function as a field of experimentation and evaluation in which to test solutions. (Jean-Francois)

Expectations and value propositions. Value creation is a cooperative endeavor that gives rise to the emergence of relationships. Relationships support the coordination of multiple activities in marketing systems. Their continuity is influenced by actors' perceptions of fulfilled or broken promises or their reaction to fulfilled or disappointed expectations, which are expressed 
in value propositions (see Grönroos 2000, 2009). Actors develop proposals for the input of resources or the coordination of activities; they make promises to one another, for example, about their performance or the characteristics of certain resources. With reference to S-D logic that value emerges in use processes and over time, Frow and Payne (2011, p. 225) argue that value propositions "set expectations of value in-use." In this regard, value propositions have a "key coordination role" within networks (Frow and Payne 2011, p. 231); against the backdrop of learning processes, they reflect past value configurations and anticipate future value configurations (see Vargo and Lusch 2008). For this reason, we include "value proposition/value proposal" in the conceptual framework. As Layton (2011, p. 269) notes, the content of exchanges "centre[s] on the value propositions made by sellers." Value propositions express the expectations of role takers such as customers, providers, and their respective stakeholders (Frow and Payne 2011). They can also address value for macro-level entities such as communities, societies, or ecological systems (Shultz and Holbrook 1999).

Social action. "Social action" is the common denominator of the various types of actions in marketing systems that give rise to the emergence of, or arise from, markets, groups, organizations, and networks. We refer to Weber's (1947, p. 88) definitions of the concepts of action and social action: "In 'action' is included all human behavior when and in so far as the acting individual attaches subjective meaning to it.... Action is social in so far as, by virtue of the subjective meaning attached to it by the acting individual (or individuals), it takes account of the behavior of others and is thereby oriented in its course."

In fact, these cloth exchange parties are locations of opulence; it's so much that's there. We have produced so much abundance and, abundance means that all have too much stuff in the wardrobe.... And this act... I don't need this anymore, but perhaps others can make use of it. (Heike)

Of course, this is something one could name "exchange good." Social connections. Sure thing. Loneliness is becoming an issue more and more. (Katrin)

"Economic action" can be considered a special case of "social action": "Action will be said to be "economically oriented' so far as, according to its subjective meaning, it is concerned with the satisfaction of a desire for 'utilities' (Nutzleistungen)... 'Economic action' (Wirtschaften) is a peaceful use of the actor's control over resources, which is primarily economically oriented" (Weber 1947, p. 158). Value propositions are an example of economic action as social action: The value proposition is of relevance for each actor who wants to be informed about what is valuable for others. Individuals engage in value creation activities because of the expectation of economic value, which is formed from the individual's ends and the value proposition of another party or other parties.

\section{The Outcome of a Marketing System}

Growth ideology that links growth with progress or the future of a nation (Asmussen 2015) or regards growth as a precondition for the creation of benefits for particular social groups or as a means for mitigating social conflicts, respectively, has been criticized from de-growth and post-growth perspectives. Many actors engaged in alternative economies have taken up de-growth as a political slogan (Latouche 2010) in an attempt to realize styles of life and work that do not draw on the ideology of growth and progress.

In German-speaking areas, the concept of postwachstum (post-growth) shapes the discussion of economic growth, suggesting that economic growth hinders solving ecological and societal problems (Bauhardt 2014; Loske 2015; Seidl and Zahrnt 2010). Post-growth theorists contend that economic growth threatens the environment, which is the case when energy-efficient investments simultaneously increase production and consumption (the so-called rebound effect) (Fournier 2008; Jackson 2009b; Van den Bergh 2011).

Regarding the concept of de-growth, Helm, Wooliscroft, and Rahtz $(2012$, p. 4) state that "degrowth is based on the premise of reducing consumption for the good of society, and the natural environment." De-growth theorists argue for a shrinking economy through institutional change and suggest social and individual action as a solution (de-growth as "social choice"). French authors who use the term décroissance (Ariès 2009; Latouche 2009) disseminate the idea of a necessary social transformation. ${ }^{6}$ Lifestyles must become "decoupled" from consumption and production habits (Latouche 2009; Markantonatou 2013), the "social imaginary" (Castoriadis 1987) must be released from the faith in human domination of nature, and social relationships previously disrupted by market mechanisms must be re-vitalized.

We conjecture the theoretical relevance of the concept of wealth rather than that of growth: Growth is no end in itself; it is a means at best. So, why should growth in volume and diversity (Layton 2011) be considered an inherent, generic characteristic of marketing systems? With regard to alternative economies, it is important not to equate a self-imposed limitation to growth with a failure of the system. In alternative economies, what can grow or will grow is open to debate (Fournier 2008). An increase in the number of people working in the social sector or the number of organizations engaged in the non-profit sector may be a desired end, but not the number of resource-depleting industries:

Can an approach be developed that does not postulate growth, but abatement or equality?... If growth at all, then in the form of coordinated action being supportive to spread our ideas. (JeanFrancois)

Consequently, the observation that actors design only marketing systems in which they desire growth of some components does not mean that these actors basically fail to accept the "limits to growth" in the sense of Meadows et al. (1972). 


\section{Conclusions and Outlook}

Alternative economies are not what macromarketing scholars had in mind when they began drafting the conceptual framework and the fundamental principles of the marketing-systems approach (see Layton and Grossbart 2006; Mittelstaedt, Kilbourne, and Mittelstaedt 2006; Nason 2011). We developed a working definition of the concept of alternative economy and proposed a modification of the conceptual framework to include essential concepts and distinctions such as economic, social, and ecological value.

Our findings help further develop the theory (Alvesson and Kärreman 2007). The applicability of the marketingsystems approach to alternative economies would be tantamount to an increase in its range of applications and is indicative of its problem-solution capability (Kuhn 1962; Laudan 1977). The marketing-systems approach is a source of knowledge that can improve the actors' understanding of their activities and practices and can inform them about possible action consequences and their assessment from an academic standpoint. In our study, for example, we found that not all interviewees were able to describe the outcome of the value creation processes in which they are involved, the service they intend to offer to other entities, or the content of their value propositions in their own words. Although value creation is essential for the study of alternative economies, value creation in alternative economies is barely understood. The marketing-systems approach, in combination with other approaches (see Layton 2016), can enhance the knowledge about alternative economies and contribute to the solution of problems existing within and for them.

In accordance with this is that most of the actors engaged in alternative economies conceive of their projects primarily as something from which they want to learn. The possibility of failure is included in that view. Following Gibson-Graham (2006), our research collects and analyzes information about value creation activities in and for alternative organizations "by formalizing and making transportable its [the organization's] experience." The kind of knowledge and reflection researchers generate about these processes in both theoretical and practical regards is useful for alternative economies, which often have the character of (social) experiments (Gibson-Graham 2006; Seyfang and Longhurst 2016).

While, according to our adapted conceptual framework, alternative economies can be described and analyzed in terms of the marketing-systems approach, two interpretations of our findings are possible. First, it could be argued that alternative and "regular" (non-alternative) economies should give rise to two variants of the marketing-systems approach. This means that the established conceptual framework can be maintained and used for the description and analysis of non-alternative economies as well. The conceptual framework we suggest herein would then be reserved for the description and analysis of alternative economies. Second, our conceptual frameworkthat is, the broader one - can be used for the study of both alternative and "regular" economies. At the given point in time, we cannot say which path is the more promising or "better" one, though we lean toward the second option.

The findings of this study contribute to the understanding of the various ways actors make use of their agency and try to emancipate from what scholars have identified as growth ideology (Hoßfeld 2015). Alternative-economy initiatives show that there are alternatives to the established (i.e., regular) ways of conceiving of and conducting economic activities.

There are several research opportunities and open questions regarding the phenomenon of alternative economies. Our modification of the conceptual framework is a starting point calling for the further refinement of our proposal. Empirical investigation, for example, may help improve our understanding of how economic, social, and ecological value creation in alternative economies differs from value creation in "regular" economies. In addition, the question arises if and how initiators of alternative economies vary from social entrepreneurs or founders of sustainable businesses. Furthermore, we argued that actors in alternative economies strive to create economic, social, and ecological value. According to the marketing-systems approach, economic value creation is given by definition, and a definitional characteristic needs no empirical proof. The opposite is true in the case of social and ecological value. It is therefore of interest whether empirical evidence exists to support a statement such as "All actors in alternative economies aim to create social and ecological value." Thus, the study of alternative economies gives rise to a particular type of empirical claims, that is, law-like generalizations (Hunt 1971). We hope to have initiated a fruitful discussion about what Hunt (1971) has called the theoretical structure of a theory and the applicability of the marketingsystems approach to alternative economies.

\section{Acknowledgments}

The authors thank Maik Günther for his critical comments on a previous version of this paper. We also thank the editor, the associate editor and the reviewers for their support and constructive comments.

\section{Declaration of Conflicting Interests}

The author(s) declared no potential conflicts of interest with respect to the research, authorship, and/or publication of this article.

\section{Funding}

The author(s) received no financial support for the research, authorship, and/or publication of this article.

\section{ORCID iD}

Michaela Haase (D) http://orcid.org/0000-0002-4228-8589

\section{Notes}

1. The scope and understanding of the political economy is not restricted to what is called "economics" today. Max Weber, for example, "was appointed Professor of Political Economy and Financial Science at the University of Freiburg in April 1894" (Tribe 2012, p. 282).

2. Graeber $(2001$, p. 1) refers to "'values' in the sociological sense: conceptions of what is ultimately good, proper, or desirable in human life." 
3. Fournier (2008, p. 541) plays down the relevance of the environmental concerns of the de-growth movement: "Thus maybe the main contribution of the degrowth movement to environmental politics and debates is that through its emphasis on 'escaping from the economy' it provides both conceptual and practical strategies for challenging the growth economy; and it does this by inviting us to rethink economic practices in terms of democratic choices and acts of citizenship." For a criticism of the anthropocentric view of the de-growth movement, see Mang and Reed (2015).

4. We neglect, for example, valuations related to unconscious mental processes.

5. Against the backdrop of the available division of labor among academic disciplines, what is now labeled "economics" did not exist at the time of classical and early neoclassical economics.

6. Latouche (2010) proposes using "decreasing growth" as a synonym of décroissance.

\section{References}

Alaimo, Katherine, Thomas M. Reischl, and Julie Ober Allen (2010), "Community Gardening, Neighborhood Meetings, and Social Capital,” Journal of Community Psychology, 38 (4), 497-514.

Alvesson, Mats and Dan Kärreman (2007), "Constructing Mystery: Empirical Matters in Theory Development," Academy of Management Review, 32 (4), 1265-81.

Ariès, Paul (2009), La Décroissance. Un Nouveau Projet Politique. Golias: Villeurbanne.

Asmussen, Jörg (2015), “Wovon wollen wir morgen leben?” [How to make a living tomorrow?] Die Berliner Republik-Das Debattenmagazin, March, (accessed August 16, 2015), [available at http:// www.b-republik.de/aktuelle-ausgabe/wovon-wollen-wir-morgenleben].

Bauhardt, Christine (2014), "Solutions to the Crisis? The Green New Deal, Degrowth, and the Solidarity Economy: Alternatives to the Capitalist Growth Economy from an Ecofeminist Economics Perspective," Ecological Economics, 102 (4), 60-68.

Beinhocker, Eric D. (2006), The Origin of Wealth: Evolution, Complexity, and the Radical Remaking of Economics. Boston, MA: Harvard Business School Press.

Benkler, Yochai (2004), "Sharing Nicely: On Shareable Goods and the Emergence of Sharing as a Modality of Economic Production," The Yale Law Journal, 114 (2), 273-358.

Bianchi, Constanza and Grete Birtwistle (2010), "Sell, Give Away, or Donate: An Exploratory Study of Fashion Clothing Disposal Behaviour in two Countries," International Review of Retail, Distribution and Consumer Research, 20 (3), 353-68.

Burger, Joanna, Michael Kochfeld, Christian Jeitner, and Taryn Pittfield (2011), "Comparing Perceptions of the Important Environmental Characteristics of the Places People Engage in Consumptive, Non-consumptive and Spiritual Activities," Journal of Risk Research, 14 (10), 1219-36.

Campana, Mario, Andreas Chatzidakis, and Mikko Laamanen (2017), "Introduction to the Special Issue: A Macromarketing Perspective on Alternative Economies," Journal of Macromarketing, 37 (2), 125-30.

Castoriadis, Cornelius (1987), The Imaginary Institution of Society. Cambridge, MA: Polity Press.
Chang, Ariana Eunjung (2012), "In Spain, Financial Crisis Feeds Expansion of a Parallel, Euro-Free Economy," The Washington Post, August 27, (accessed August 3, 2015), [available at http:// www.washingtonpost.com/business/economy/in-spain-financialcrisis-feeds-expansion-of-a-parallel-euro-free-economy/2012/08/ 27/53ed3552-e00f-11e1-a19c-fcfa365396c8_story.html].

Chatzidakis, Andreas, Pauline Maclaran, and Alan Bradshaw (2012), "Heterotopian Space and the Utopics of Ethical and Green Consumption," Journal of Marketing Management, 28 (3/4), 494-515.

Christensen, Larry B., R. Burke Johnson, and Lisa A. Turner (2015), Research Methods, Design, and Analysis. Boston, MA: Pearson.

Cole, Raymond J. (2015), "Net-Zero and Net-Positive Design: A Question of Value," Building Research \& Information, 43 (1), 1-6.

Coleman, James S. (1986), Individual Interests and Collective Action: Selected Essays. Cambridge, MA: Cambridge University Press.

Cunningham, Kimberly (2008), "Social Networks," in Encyclopedia of Social Problems, Vincent N. Parillo, ed. Thousand Oaks, CA: Sage, 885-86.

Del Moral, Lucía (2014), “Alternative Time-Based Markets and Gender: Public Policy Implications of Timebanking in a Comparative European Context," in Proceedings of the 39th Annual Macromarketing Conference, Alan Bradshaw, Mikko Laamanen, and Alex Reppel, eds. London, UK: King's College, 102-05.

DiMaggio, Paul J. (1988), "Interest and Agency in Institutional Theory," in Institutional Patterns and Organizations: Culture and Environment, Lynn G. Zucker, ed. Cambridge, MA: Ballinger, 3-21.

Echeverri, Per and Per Skålén (2011), "Co-Creation and CoDestruction: A Practice-Theory Based Study of Interactive Value Formation," Marketing Theory, 11 (3), 351-73.

Edvardsson, Bo, Michael Kleinaltenkamp, Bard Tronvoll, Patricia McHugh, and Charlotta Windahl (2014), "Institutional Logics Matter when Coordinating Resource Integration," Marketing Theory, 14 (3), 291-309.

Edvardsson, Bo, Bard Tronvoll, and Thorsten Gruber (2011), "Expanding Understanding of Service Exchange and Value CoCreation: A Social Construction Approach," Journal of the Academy of Marketing Science, 39 (2), 327-39.

Fournier, Valérie (2008), "Escaping from the Economy: The Politics of Degrowth," International Journal of Sociology and Social Policy, 28 (11/12), 528-45.

Friedland, Roger and Robert R. Alford (1991), "Bringing Society Back In: Symbols, Practices, and Institutional Contradictions," in The New Institutionalism in Organizational Analysis, Walter W. Powell and Paul J. DiMaggio, eds. Chicago: University of Chicago Press, 232-63.

Frow, Pennie and Adrian Payne (2011), "A Stakeholder Perspective on the Value Creation Concept," European Journal of Marketing, 45 (1/2), 223-40.

Fry, Marie-Louise and Michael Jay Polonsky (2004), "Examining the Unintended Consequences of Marketing," Journal of Business Research, 57 (11), 1303-06.

Gawer, Annabelle and Nelson Phillips (2013), "Institutional Work as Logics Shift: The Case of Intel's Transformation to Platform Leader," Organization Studies, 34 (8), 1035-71. 
Gibson-Graham, J. Katherine (2003), "Enabling Ethical Economies: Cooperativism and Class," Critical Sociology, 29 (2), 123-61.

Gibson-Graham, J. Katherine (2006), The End of Capitalism (As We Knew It): A Feminist Critique of Political Economy. London, UK: University of Minnesota Press.

Gibson-Graham, J. Katherine and Gerda Roelvink (2011), "The Nitty Gritty of Creating Alternative Economies," Social Alternatives, 30 (1), 29-33.

Graeber, David (2001), Towards an Anthropological Theory of Value: The False Coin of Our Own Dreams. New York: Palgrave.

Grönroos, Christian (2000), "Relationship Marketing: The Nordic Perspective," in Handbook of Relationship Marketing, Jagdish N. Sheth and Atul Parvatiyar, eds. Thousand Oaks, CA: Sage, 95-117.

Grönroos, Christian (2009), "Marketing as Promise Management: Regaining Customer Management for Marketing," Journal of Business and Industrial Marketing, 24 (5/6), 351-59.

Haase, Michaela (2015), "Values-based Value Creation and Responsibility - On the Relationship of 'Doing Business' and 'Doing CSR'," Journal for Business, Economics \& Ethics, 16 (3), 339-68.

Haase, Michaela and Doreén Pick (2015), "Value Creation in Sharing Networks: Towards a Typology of Sharing Networks," in Forum Dienstleistungsmanagement. Interaktive Wertschöpfung durch Dienstleistungen [Forum Services Management. Interactive Value Creation through Services], Manfred Bruhn, and Karsten Hadwich, eds. Wiesbaden: Gabler Verlag, 439-68.

Hart, Stuart L. and Mark B. Milstein (2003), "Creating Sustainable Value," Academy of Management Executive, 17 (2), 56-69.

Helm, Sabrina V., Ben Wooliscroft, and Don R. Rahtz (2012), "The Role of Marketing in Degrowth," in Proceedings of the 37th Annual Macromarketing Conference 2012, Michaela Haase and Michael Kleinaltenkamp, eds. Berlin, Germany: Freie Universität Berlin, 4-6.

Hiwaki, Kensei (2015), "Alternative Economics and Sustainable Future: Diverse Cultures/Beliefs/Values as Indispensable Factors," Cybernetics and Systems: An International Journal, 46 (6/7), 588-604.

Hodkinson, Paul (2016), "Grounded Theory and Inductive Research," in Researching Social Life, Nigel Gilbert and Paul Stoneman, eds. London: Sage, 97-117.

Hoßfeld, Heiko (2015), "Mythos und Ideologie des wirtschaftlichen Fortschritts," [Myth and Ideology of Economic Progress], in Erkenntnis und Fortschritt: Beiträge aus Personalforschung und Managementpraxis. Festschrift für Albert Martin, Thomas Behrends, Thorsten Jochims, and Werner Nienhüser, eds. München, Mering: Rainer Hampp Verlag, 6-11.

Hunt, Shelby D. (1971), "The Morphology of Theory and the General Theory of Marketing," Journal of Marketing, 35 (2), 65-68.

Jackson, Tim (2009a), Prosperity without Growth: Economics for a Finite Planet. Oxon: Earthscan.

Jackson, Tim (2009b), "Beyond the Growth Economy," Journal of Industrial Ecology, 13 (4), 487-90.

Jevons, William S. (1866), The Coal Question: An Inquiry Concerning the Progress of the Nation, and the Probable Exhaustion of Our Coal-Mines. London, UK: Macmillan and Co.
Karababa, Eminegül and Dannie Kjeldgaard (2014), "Value in Marketing: Toward Sociocultural Perspectives," Marketing Theory, 14 (1), 119-27.

Kleinaltenkamp, Michael, Rod Brodie, Penny Frow, Tim Hughes, Linda Peters, and Herbert Woratschek (2012), "Resource Integration," Marketing Theory, 12 (2), 201-05.

Kluckhohn, Klyde (1951), "Values and Value-Orientations in the Theory of Action: An Exploration in Definition and Classification," in Towards a Theory of Action, Talcott Parsons and Edward Shils eds. Cambridge, MA: Harvard University Press, 388-433.

Kuhn, Thomas S. (1962), The Structure of Scientific Revolutions. Chicago: University of Chicago Press.

Laamanen, Mikko, Stefan Wahlen, and Mario Campana (2015), "Mobilising Collaborative Consumption Lifestyles: A Comparative Frame Analysis of Time Banking," International Journal of Consumer Studies, 39 (5), 459-67.

Laczniak, Gene R. and Nicholas J. C. Santos (2011), "The Integrative Justice Model for Marketing to the Poor: An Extension of S-D Logic to Distributive Justice and Macromarketing," Journal of Macromarketing, 31 (2), 135-47.

Latouche, Serge (2009), Farewell to Growth. Cambridge, MA: Polity Press.

Latouche, Serge (2010), "Degrowth," Journal of Cleaner Production, $18(6), 519-22$.

Laudan, Larry (1977), Progress and Its Problems: Toward a Theory of Scientific Growth. Berkeley: University of California Press.

Lautermann, Christian (2013), "The Ambiguities of (Social) Value Creation: Towards an Extended Understanding of Entrepreneurial Value Creation for Society," Social Enterprise Journal, 9 (2), 184-202.

Lawrence, Thomas B. and Roy Suddaby (2006), "Institutions and Institutional Work," in SAGE Handbook of Organization Studies, Stewart R. Clegg, Cynthia Hardy, Thomas B. Lawrence, and Walter Nord, eds. London: Sage, 215-54.

Layton, Roger A. (2007), "Marketing Systems: A Core Macromarketing Concept," Journal of Macromarketing, 27 (3), 227-42.

Layton, Roger A. (2009), “On Economic Growth, Marketing Systems, and the Quality of Life," Journal of Macromarketing, 29 (4), 349-62.

Layton, Roger A. (2011), "Towards a Theory of Marketing Systems," European Journal of Marketing, 45 (1/2), 259-76.

Layton, Roger A. (2015), "Formation, Growth, and Adaptive Change in Marketing Systems," Journal of Macromarketing, 35 (3), 302-19.

Layton, Roger A. (2016), "There Could Be More to Marketing Than You Might Have Thought! An Invited Paper," Australian Marketing Journal, 24 (1), 2-7.

Layton, Roger A. and Sanford Grossbart (2006), "Macromarketing: Past, Present and Possible Future," Journal of Macromarketing, 26 (2), 193-213.

Lazer, William (1969), "Marketing's Changing Social Relationships," Journal of Marketing, 33 (1), 3-9.

Lloveras, Javier and Nikolaos-Foivos Ntounis (2014), “Alternative Currencies: The Reinvention of Marketing Systems for Degrowth Transitions," in Proceedings of the 39th Annual Macromarketing 
Conference, Alan Bradshaw, Mikko Laamanen, and Alex Reppel, eds. Macromarketing Society, 55-57.

Lloveras, Javier and Lee Quinn (2017), “Growth and Its Discontents: Paving the Way for a More Productive Engagement with Alternative Economic Practices," Journal of Macromarketing, 37 (2), 131-42.

Löbler, Helge (2013), "Service-Dominant Networks - An Evolution from the Service-Dominant Logic Perspective," Journal of Service Management, 24 (4), 420-34.

Loske, Reinhard (2015), "Nachhaltigkeit erfordert pluralistische Wirtschaftsstile," [Sustainability Requires Pluralist Economic Styles], Neue Gesellschaft Frankfurter Hefte, 5, 46-48.

Lounsbury, Michael and Eva Boxenbaum (2013), "Institutional Logics in Action," in Institutional Logics in Action, Part A. Research in the Sociology of Organizations, 39A, Michael Lounsbury and Eva Boxenbaum, eds. Bingley, UK: Emerald, 3-22.

Lusch, Robert F. and Stephen L. Vargo (2014), Service-Dominant Logic: Premises, Perspectives, Possibilities. Cambridge, UK: Cambridge University Press.

Lusch, Robert F., Stephen L. Vargo, and Alan J. Malter (2006), "Marketing as Service-Exchange: Taking a Leadership Role in Global Marketing Management," Organizational Dynamics, 35 (3), 264-78.

Mang, Pamela and Bill Reed (2015), "The Nature of Positive," Building Research \& Information, 43 (1), 7-10.

Markantonatou, Maria (2013), "From 'the Limits to Growth' to 'Degrowth': Discourses of Critique of Growth in the Crises of the 1970s and 2008," Working Paper der DFG - KollegforscherInnengruppe Postwachstumsgesellschaften, Nr. 05/2013, Jena.

McPherson, Chad M. and Michael Sauder (2013), "Logics in Action: Managing Institutional Complexity in a Drug Court," Administrative Science Quarterly, 58 (2), 165-96.

Meadows, Donella H., Dennis L. Meadows, Jorgen Randers, and William W. Behrens III (1972), The Limits to Growth: A Report for the Club of Rome's Project on the Predicament of Mankind. New York: Universe Books.

Miebach, Bernhard (1991), Soziologische Handlungstheorie: Eine Einführung, [Sociological Action Theory: An Introduction]. Opladen: Westdeutscher Verlag.

Mincyte, Diana (2008), "Social Capital," in Encyclopedia of Social Problems, Vincent N. Parillo, ed. Thousand Oaks, CA: Sage, 862-63.

Mittelstaedt, John D., C. R. Duke, and Robert A. Mittelstaedt (2009), "Health Care Choices in the United States and the Constrained Consumer: A Marketing Systems Perspective on Access and Assortment in Health Care," Journal of Public Policy \& Marketing, 28 (1), 95-101.

Mittelstaedt, John D., William E. Kilbourne, and Robert A. Mittelstaedt (2006), "Macromarketing as Agorology: Macromarketing Theory and the Study of the Agora," Journal of Macromarketing, 26 (2), 131-42.

Mittelstaedt, John D., Clifford Shultz II, William E. Kilbourne, and Mark Peterson (2014), "Sustainability as Megatrend: Two Schools of Macromarketing Thought," Journal of Macromarketing, 34 (3), 253-64.
Mundt, JoNel (1993), "Externalities: Uncalculated Outcomes of Exchange," Journal of Macromarketing, 13 (2), 46-53.

Nason, Robert W. (1989), "The Social Consequences of Marketing: Macromarketing and Public Policy," Journal of Public Policy \& Marketing, 8 (1), 242-51.

Nason, Robert W. (2011), "Institutionalization of Macromarketing," Journal of Historical Research in Marketing, 3 (2), 261-68.

Nutzinger, Hans G. (2012), "Dogmen- und realhistorische Aspekte des Wohlfahrtsbegriffs," [Dogmatic and Historical Aspects of the Concept of Welfare], Joint Discussion Paper Series in Economics by the Universities of Aachen, Gießen, Göttingen, Kassel, Marburg, Siegen, (accessed February 5, 2015), [available at http://www.unimarburg.de/fb02/makro/forschung/magkspapers/index_ html\%28magks\%29].

Ordóñez, Camilo and Peter N. Duinker (2014), "Urban Forest Values of the Citizenry in Three Colombian Cities," Society and Natural Resources, 27 (8), 834-49.

Papaoikonomou, Eleni and Carmen Valor (2017), "The Institutionalization of Alternative Economies: The Processes of Objectification in Time Banks," Journal of Macromarketing, 37 (2), 167-79.

Prahalad, Coimbatore K. and Venkat Ramaswamy (2004), The Future of Competition - Co-Creating Unique Value with Customers. Boston, MA: Harvard Business School Press.

Schor, Juliet and Connor Fitzmaurice (2015), "Collaborating and Connecting: The Emergence of a Sharing Economy," in Handbook on Research on Sustainable Consumption, Lucia Reisch and John Thogersen, eds. Cheltenham, UK: Edward Elgar, 410-25.

Scott, Richard W. (1995), Institutions and Organizations. Ideas, Interests and Identities. Thousand Oaks, CA: Sage.

Seidl, Irmi and Angelika Zahrnt (2010), Postwachstumsgesellschaft. Konzepte für die Zukunft. [Post-Growth Society. Concepts for the Future]. Marburg: Metropolis.

Seyfang, Gill (2003), “'With a Little Help from My Friends.' Evaluating Time Banks as a Tool for Community Self-Help," Local Economy, 18 (3), 257-64.

Seyfang, Gill (2004), "Working Outside the Box: Community Currencies, Time Banks and Social Inclusion," Journal of Social Policy, 33 (1), 49-71.

Seyfang, Gill and Noel Longhurst (2016), "What Influences the Diffusion of Grassroots Innovations for Sustainability? Investigating Community Currency Niches," Technology Analysis \& Strategic Management, 28 (1), 1-23.

Shultz, Clifford J., II (2007), "Marketing as Constructive Engagement," Journal of Public Policy \& Marketing, 26 (2), 293-301.

Shultz, Clifford J., II, and Morris B. Holbrook (1999), "Marketing and the Tragedy of the Commons: A Synthesis, Commentary, and Analysis for Action," Journal of Public Policy \& Marketing, 18 (2), 218-29.

Sridharan, Srinivas, Elliot Maltz, Madhubalan Viswanathan, and Samir Gupta (2014), "Transformative Subsistence Entrepreneurship: A Study in India," Journal of Macromarketing, 34 (4), 486-504.

Stavenhagen, Gerhard (1969), Geschichte der Wirtschaftstheorie, [History of Economic Theory]. Göttingen: Vandenhoeck \& Ruprecht. 
Thornton, Patricia H. and William Ocasio (1999), "Institutional Logics and the Historical Contingency of Power in Organizations: Executive Succession in Higher Education Publishing Industry, 1958-1990," American Journal of Sociology, 105 (3), 805-43.

Tribe, Keith (2012), "Max Weber: The Works," Economy and Society, 41 (2), 282-98.

Valor, Carmen and Eleni Papaoikonomou (2014), "The Nature of Exchange in Time Banks: Mapping the Territory and Identifying the Phenomenon," in Proceedings of the 39th Annual Macromarketing Conference, Alan Bradshaw, Mikko Laamanen, and Alex Reppel, eds. London, UK: King's College, 94-97.

Van den Bergh, Jeroen C. J. M. (2011), "Environment Versus Growth A Criticism of 'Degrowth' and a Plea for 'a-growth'," Ecological Economics, 70 (5), 881-90.

Vann, John W. and Erdogan Kumcu (1995), “Achieving Efficiency and Distributive Justice in Marketing Programs for Economic Development," Journal of Macromarketing, 15 (2), 5-22.

Varey, Richard J. (2002a), Marketing Communication: Principles and Practice. London, UK: Routledge.

Varey, Richard J. (2002b), Relationship Marketing: Dialogue and Networks in the E-Commerce Era. Chichester, UK: John Wiley.

Varey, Richard J. (2010), "Marketing Means and Ends for a Sustainable Society: A Welfare Agenda for Transformative Change," Journal of Macromarketing, 30 (2), 112-26.

Varey, Richard J. (2012), "The Marketing Future Beyond the Limits of Growth,” Journal of Macromarketing, 32 (4), 424-33.

Vargo, Stephen L. (2011), "Market Systems, Stakeholders and Value Propositions: Toward a Service-Dominant Logic-Based Theory of the Market," European Journal of Marketing, 45 (1/2), 217-22.

Vargo, Stephen L. and Robert F. Lusch (2008), "Service-Dominant Logic: Continuing the Evolution," Journal of the Academy of Marketing Science, 36 (1), 1-10.

Wakefield, Sarah, Fiona Yeudall, Carolin Taron, Jennifer Reynolds, and Ana Skinner (2007), "Growing Urban Health: Community
Gardening in South-East Toronto," Health Promotion International, 22 (2), 92-101.

Weber, Max (1947), The Theory of Social and Economic Organization. Edited with an Introduction by Talcott Parsons. New York: The Free Press.

White, Mark D. (2013), "Can We - and Should We - Measure WellBeing?” Review of Social Economy, 71 (4), 526-33.

Wilson, Jonathan (2014), Essentials of Business Research: A Guide to Doing Your Research Project. London, UK: Sage.

\section{Author Biographies}

Michaela Haase is head of the Center for Marketing and Ethics, Marketing-Department at Freie Universität Berlin, Germany. Her fields of expertise include marketing, institutional theories, business and economic ethics, and philosophy of science.

Ingrid Becker is a doctoral candidate and research assistant at Friedrich-Alexander-Universität Erlangen-Nürnberg (FAU), Germany. She teaches marketing at the graduate level with a particular interest in philosophical and epistemological foundations of marketing theory. Ingrid is a member of the Transatlantic Doctoral Academy (TADA), an interdisciplinary $\mathrm{PhD}$ program in the field of business, economics, and ethics at the University of St. Gallen. In her dissertation, Ingrid studies the intersection of belief systems and provisioning systems such as alternative economies.

Doreén Pick is professor of Marketing at the University of Applied Sciences Merseburg (Germany). She also teaches at the FOM Hochschule Berlin (Germany). Her research focus covers services marketing and relationship marketing. Her work is published in academic journals such as Journal of the Academy of Marketing Science, Journal of Service Research, Journal of International Marketing and Energy Policy. 